\title{
Process-Induced Modifications on Quality Attributes of Cassava (Manihot esculenta Crantz) Flour
}

\author{
Elohor Oghenechavwuko Udoro ${ }^{1,2}$, Tonna Ashim Anyasi ${ }^{1,3, * \mathbb{D}}$ and Afam Israel Obiefuna Jideani ${ }^{1,4}$ (D) \\ 1 Department of Food Science and Technology, Faculty of Science, Engineering and Agriculture, \\ University of Venda, Thohoyandou 0950, South Africa; udoroelohor@yahoo.com (E.O.U.); \\ afam.jideani@univen.ac.za (A.I.O.J.) \\ 2 Department of Food Technology, School of Industrial Technology, Akanu Ibiam Federal Polytechnic, \\ Afikpo-Unwana 490102, Nigeria \\ 3 Agro-Processing and Postharvest Technologies Division, Agricultural Research Council—Tropical and \\ Subtropical Crops, Private Bag X11208, Nelspruit 1200, South Africa \\ 4 Special Interest Group Post Harvest Handling, ISEKI-Food Association, Muthgasse 18, 1190 Vienna, Austria \\ * Correspondence: AnyasiT@arc.agric.za
}

Citation: Udoro, E.O.; Anyasi, T.A.; Jideani, A.I.O. Process-Induced Modifications on Quality Attributes of Cassava (Manihot esculenta Crantz) Flour. Processes 2021, 9, 1891. https://doi.org/10.3390/pr9111891

Academic Editor:

Jean-Louis Lanoiselle

Received: 5 August 2021

Accepted: 14 October 2021

Published: 22 October 202

Publisher's Note: MDPI stays neutral with regard to jurisdictional claims in published maps and institutional affiliations.

Copyright: (c) 2021 by the authors. Licensee MDPI, Basel, Switzerland. This article is an open access article distributed under the terms and conditions of the Creative Commons Attribution (CC BY) license (https:/ / creativecommons.org/licenses/by/ $4.0 /)$.

\begin{abstract}
Cassava flour (CF) is a suitable representative and one of the easiest shelf-stable food products of the edible portion of the highly perishable cassava root (Manihot esculenta Crantz). The quality and type of $\mathrm{CF}$ are dependent on processing variables. Broadly categorized into fermented and unfermented CF, unfermented CF is white, odorless, and bland, while fermented CF has a sour flavor accompanied by its characteristic odor. The use of fermented CF as a composite is limited because of their off-odors. Modifications in CF processing have given rise to prefixes such as: modified, unmodified, gelatinized, fortified, native, roasted, malted, wet, and dry. Consumed alone, mostly in reconstituted dough form with soups, CF may also serve as a composite in the processing of various flour-based food products. Fermenting with microorganisms such as Rhizopus oryzae and Saccharomyces cerevisiae results in a significant increase in the protein content and a decrease in the cyanide content of CF. However, there are concerns regarding its safety for consumption. Pre-gelatinized CF has potential for the textural and structural improvement of bakery products. The average particle size of the CF also influences its functional properties and, subsequently, the quality of its products. Cassava flour is best stored at ambient temperature. Standardizing the processing of CF is a challenge because it is mostly processed in artisanal units. Furthermore, each variety of the root best suits a particular application. Therefore, understanding the influence of processing variables on the characteristics of CF may improve the utilization of CF locally and globally.
\end{abstract}

Keywords: cassava; processing variables; cassava utilization; flour; starch; tuber crops

\section{Introduction}

Cassava (Manihot esculenta Crantz) is a woody perennial shrub with tuberous roots. The genus Manihot belongs to the family Euphorbiaceae and is also called Tapioca, Mandioca, Yucca, and Manioc in different languages [1]. History has it that the crop was domesticated between 7000 and 9000 years ago in South America [2]. It was first imported to Africa by the Portuguese in the eighteenth century, but it is now widely grown with different varieties (Figure 1) in tropical and subtropical regions of Asia, Africa, and Latin America. It currently ranks as the third most important source of carbohydrate in the tropics for human consumption after maize and rice [3]. The plant is drought-resistant, adaptive to harsh climatic conditions, productive in marginal soils, and flexible in planting and harvesting seasons [4]. These admirable agronomic traits make it a reliable and low-cost vegetative crop for food security and other applications [5]. The leaves and roots are the nutritionally valuable parts of the crop, and they make up $6 \%$ and $50 \%$ of the mature plant, respectively. The enlarged tuberous roots are the main carbohydrate storage locations in cassava, and 
they are important not just because they form the bulk weight of the plant but because they are the main part of the plant consumed [6-8].

Utilization of cassava root cuts across various areas: food for humans, feed for livestock, and raw material for various industries, such as manufacturers of textiles, paper, biofuel, confectionary products, and adhesives [9]. In Africa, which is the largest producer of cassava in the world, over $80 \%$ of the root produced is used for human consumption as a major staple item [10]. In Latin America, about $40 \%$ of cassava produced is used for human consumption, while in Asia, most of the products from cassava are exported [11]. Cassava supplies about 200-500 cal/day for households in developing countries, and different forms of foods can be processed from the root $[9,12]$. A major setback to the utilization of cassava is that it deteriorates rapidly and cannot be stored for more than a few days after harvesting; therefore, the roots are quickly processed into stable products such as cassava chips and flour [13]. Cassava flour (CF) is a dry powdery product that is directly derived from milling dried cassava chips, after which it may be sieved, or it can also be processed from fresh cassava roots by grating and further subjected to other processing steps [14]. This paper sheds light on the variations in methods of CF processing and how these process-induced changes influence the flour quality.

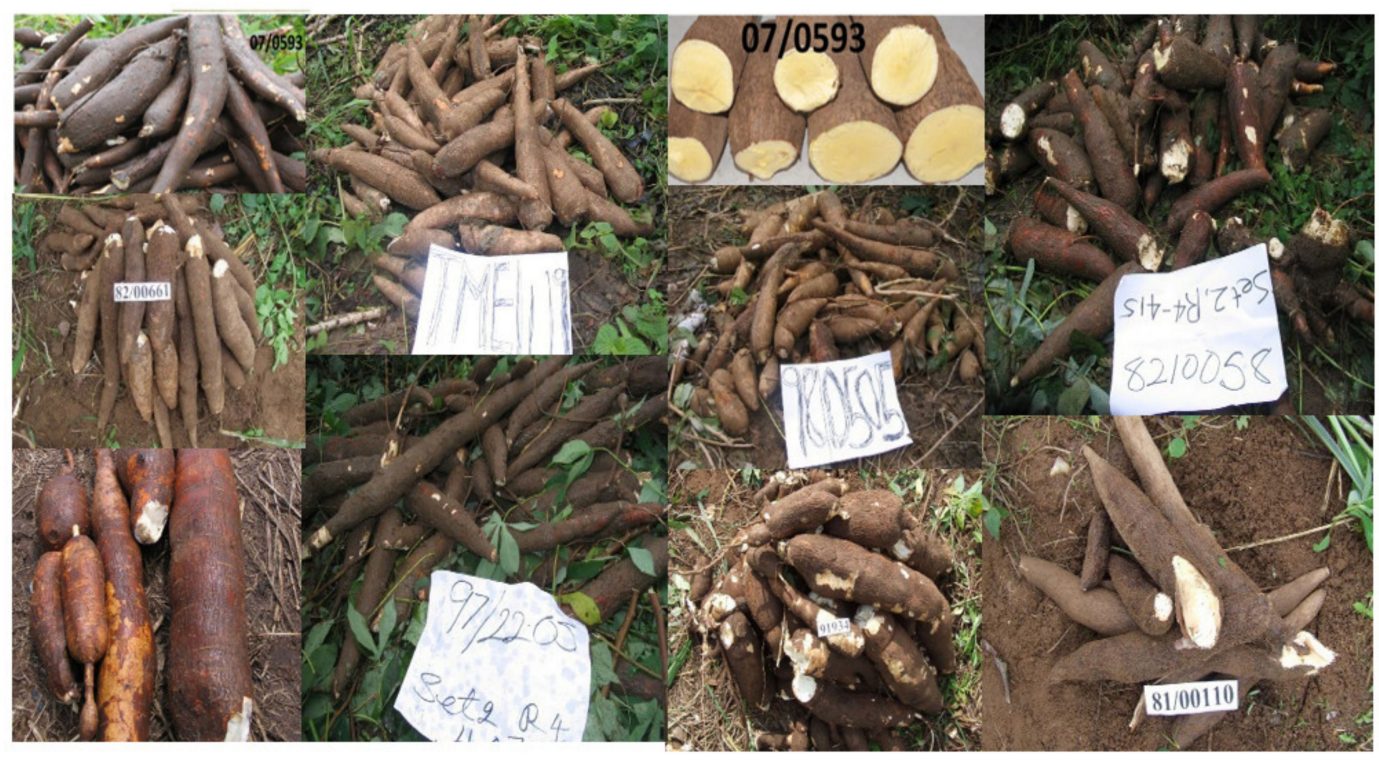

Figure 1. Photo of different varieties of cassava. Source: [15].

\section{Composition and Postharvest Deterioration of Cassava Root}

Cassava is primarily a source of carbohydrate, which accounts for about $80-90 \%$ of its proximate dry matter composition. The carbohydrate content is approximately $80 \%$ starch [16] and little quantities of sucrose (36-46 mg/g), glucose (5-14 mg/g), and maltose $(2-19 \mathrm{mg} / \mathrm{g})[6,17]$ on a dry-weight basis. The root consists of the peel and the flesh. The peel comprises $10-20 \%$ of the root. The parenchyma, which is the edible portion of the root, comprises approximately $85 \%$ of the total root weight, consisting of xylem vessels radially distributed in a matrix of starch-containing cells [18]. Cassava pulp has appreciable quantities of sugars and starches; the quantitative analysis of sugars in cassava pulp of three varieties by Otache et al. [19] showed the following ranges of values amongst the varieties: total sugar $(4.02-5.58) \%$, sucrose $(2.60-4.03) \%$, reducing sugar $(0.28-0.34) \%$, non-reducing sugar $(2.74-4.24) \%$, and starch $(27.98-38.34) \%$ on a fresh weight basis.

One major characteristic antinutrient in cassava is hydrogen cyanide ( $\mathrm{HCN})$. Hydrogen cyanide is released from the catalytic hydrolysis of two cyanogenic glucosides: linamarin and lotaustralin, occurring when tissues of the root are bruised or crushed [20]. Cassava in its unprocessed form is cyanogenic and highly toxic [21]; therefore, the roots are processed to reduce the cyanide content to safe levels before consumption $[22,23]$. 
Cassava also contains antinutrients, such as phytate, nitrate, polyphenols, and oxalate, which can reduce nutrient bioavailability. However, some of these compounds can act as anticarcinogens and antioxidants depending on the amount ingested [24]. Cassava roots contain vitamins $\mathrm{A}, \mathrm{C}$, and $\mathrm{E}$ and several minerals, such as calcium, magnesium, sodium, potassium, iron, phosphorus, and chloride $[25,26]$. These bioactive ingredients present in cassava are an indication that the tuberous root may possess some medicinal properties [25].

The fresh roots of harvested cassava cannot be stored because they deteriorate rapidly due to a process known as postharvest physiological deterioration (PPD). The utilization of cassava root is thus limited by rapid PPD, which reduces the shelf life and degrades its quality attributes [12,27]. PPD is a complex biochemical and physiological process that starts with vascular streaking, which is a blue-black coloration later followed by a microbial activity that causes complete spoilage of the root [28]. The rate of PPD sets in immediately so that deterioration and spoilage of roots occur two to three days after harvest. PPD of cassava is a global challenge that hinders the improvement of its value chain $[27,29,30]$. Studies have been conducted to understand the complex phenomenon responsible for the PPD of cassava storage roots, but still, the problem persists [27,29-35]. To reduce losses due to PPD, the roots are quickly converted to shelf-stable products [13]. Cassava flour is a shelf-stable product of cassava with simple process technology, which can subsequently be used for both industrial and domestic purposes [36,37].

\section{Processing and Yield of Cassava Flour}

Cassava flour processing has been extensively researched by individual researchers, local and international research institutes such as the International Institute for Tropical Agriculture (IITA), the Technical Centre for Agricultural and Rural Cooperation [14,38-41], and many others. The fundamental steps for processing CF from the root are washing, peeling, chipping, drying, milling, sieving, and packaging. However, in a bid to improve the product quality and meet consumers' preferences, the processing steps may be altered by the addition of other steps such as precooking, fermentation, fortification, and enrichment. Other factors such as temperature, duration, and instrumentation of each step also play important roles in CF processing. These listed processes are highlighted and briefly described in Table 1.

Dziedzoave et al. [41] stated that the yield of CF falls within the range of 13-19\%. Eriksson [42] reported the average flour yield of three cultivars as a percentage of fresh cassava weight to be 18.50; the peel and water account for the remaining weight. Falade et al. [43] reported a slightly higher value of $20.67 \%$, and Udoro et al. [44] a much higher range of 36.15-37.03\%, which was significantly influenced by peel thickness. ApeaBah et al. [45] showed that the maturity, moisture, and variety of the root influence the flour yield. The milling and sieving process also influences the recovery of flour. Adesina and Bolaji [46] reported that the pin mill gives a higher flour recovery (approximately $100 \%$ ) when compared to the hammer, attrition, and mortar mills. The basis (wet or dry) for calculating the percentage yield influences the value obtained [44]. 
Table 1. Description of cassava flour processing steps.

\begin{tabular}{|c|c|c|c|}
\hline \multirow{2}{*}{ Processing Type } & \multicolumn{2}{|c|}{ Processing Steps } & \multirow[t]{2}{*}{ References } \\
\hline & Activity and Purpose & Method & \\
\hline Sorting & $\begin{array}{l}\text { To remove spoilt and fibrous roots. Only healthy } \\
\text { roots are used. }\end{array}$ & Manually by visual inspection and discretion. & [39] \\
\hline Washing & $\begin{array}{c}\text { To remove dirt, sand, and soil that adheres to } \\
\text { surface of root. }\end{array}$ & Rinsing with clean water. & {$[14]$} \\
\hline Peeling & $\begin{array}{l}\text { To remove outer layer, the stalk, woody tips, and } \\
\text { fibrous part of the root. }\end{array}$ & $\begin{array}{l}\text { Manually with sharp knives or other abrasive } \\
\text { equipment. Efficient peeling machines are still a } \\
\text { work in progress. }\end{array}$ & {$[47-50]$} \\
\hline Grating & Crushing fresh pulp to form a mash. & Mechanical graters. & [46] \\
\hline Pressing & Dewatering of fresh mash. & $\begin{array}{l}\text { Mash in jute sacks is pressed using dewatering } \\
\text { machines such as hydraulic jack and screw press. }\end{array}$ & {$[14]$} \\
\hline Chipping & $\begin{array}{c}\text { The roots are cut into big chunks and then } \\
\text { smaller chips }(2-3 \mathrm{~cm}) \text { in length and } 1-2 \mathrm{~mm} \\
\text { thickness. }\end{array}$ & Manually with knives and chipping machines. & {$[51,52]$} \\
\hline Drying & $\begin{array}{l}\text { Reduce moisture content of fresh chips or } \\
\text { dewatered mash to about } 8-12 \% \text {. }\end{array}$ & $\begin{array}{l}\text { On surfaces under the sun, cabinet dryers, and } \\
\text { hot air oven. }\end{array}$ & {$[37,53,54]$} \\
\hline Milling & Reducing dried mash or chips to powder. & Pin, hammer, attrition, paddle, or mortar mills. & {$[46,51,55]$} \\
\hline Sieving & $\begin{array}{l}\text { To remove large particles or fibers from milled } \\
\text { chips to obtain fine flour. }\end{array}$ & Sieves of varying sizes. & {$[46,55]$} \\
\hline Fermenting & $\begin{array}{l}\text { Action of microorganisms to reduce cyanide and } \\
\text { develop flavor. }\end{array}$ & Naturally, soaking or inoculating microbes. & [56-61] \\
\hline Enriching/fortifying & Fermentation or addition of protein concentrate. & $\begin{array}{l}\text { Solid-state fermentation or co-processing with } \\
\text { protein-rich materials. }\end{array}$ & {$[62,63]$} \\
\hline Pre-gelatinising & Heating roots to gelatinize starch content. & Steaming or cooking. & {$[64-66]$} \\
\hline Packaging and storing & Cassava flour is kept till time of use. & $\begin{array}{c}\text { In paper bags, plastic bags, or buckets kept on } \\
\text { the shelf or refrigerated. }\end{array}$ & {$[67,68]$} \\
\hline
\end{tabular}

\section{Comparison of Cassava Flour and Starch: Physicochemical and Functional Properties}

Cassava flour and starch are two similar but different products obtained from the root. They are fine and powdery materials derived from milling and sifting pre-processed cassava root. The processing technology of CF is easier than that of starch. While CF is traditionally obtained by milling the dried root, the starch is extracted as slurry from the wet milling of the root [14]. The flour requires less use of water and a lower amount of byproduct and waste [36]. The components often found in flours include starch, non-starch polysaccharide, sugar, protein, lipid, and inorganic materials [69]. Although starch is the major component of $\mathrm{CF}$, other components may play a significant role in influencing the properties of the flour [69-71]. Due to the very high starch content of CF, it is sometimes referred to as starch. Navia and Villada [39] and Sulistyo et al. [62] used the term CF and cassava starch interchangeably when characterizing the microstructure of cassava flours, probably because the most evident component was starch.

A study conducted on 12 cassava varieties of different textural quality (Figure 2) reveals the properties of cassava starch and its corresponding flour.

The study showed that the pasting temperature of the latter is substantially higher than the former, whereas the reverse is the case for the onset and conclusion temperatures. Moorthy et al. [70] attributed this trend to the presence of fats and sugars, while Niba et al. [71] proposed that the amylase activity and interference of non-starch components may be responsible for this trend. Strong correlations between firmness and alpha-amylase activity, firmness, lipid contents, and fiber, as well as paste viscosity and ash, starch content, and alpha-amylase activity, were reported by Charoenkul et al. [69]. The application of these products are similar, and both may be used in the textile, paper, pharmaceutical, and food industries as a binder, thickener, or glazing agent [14,72]. However, CF is mainly consumed by humans in a reconstituted dough form and is suitable as a composite flour in the production of baked foods such as biscuits and bread. 


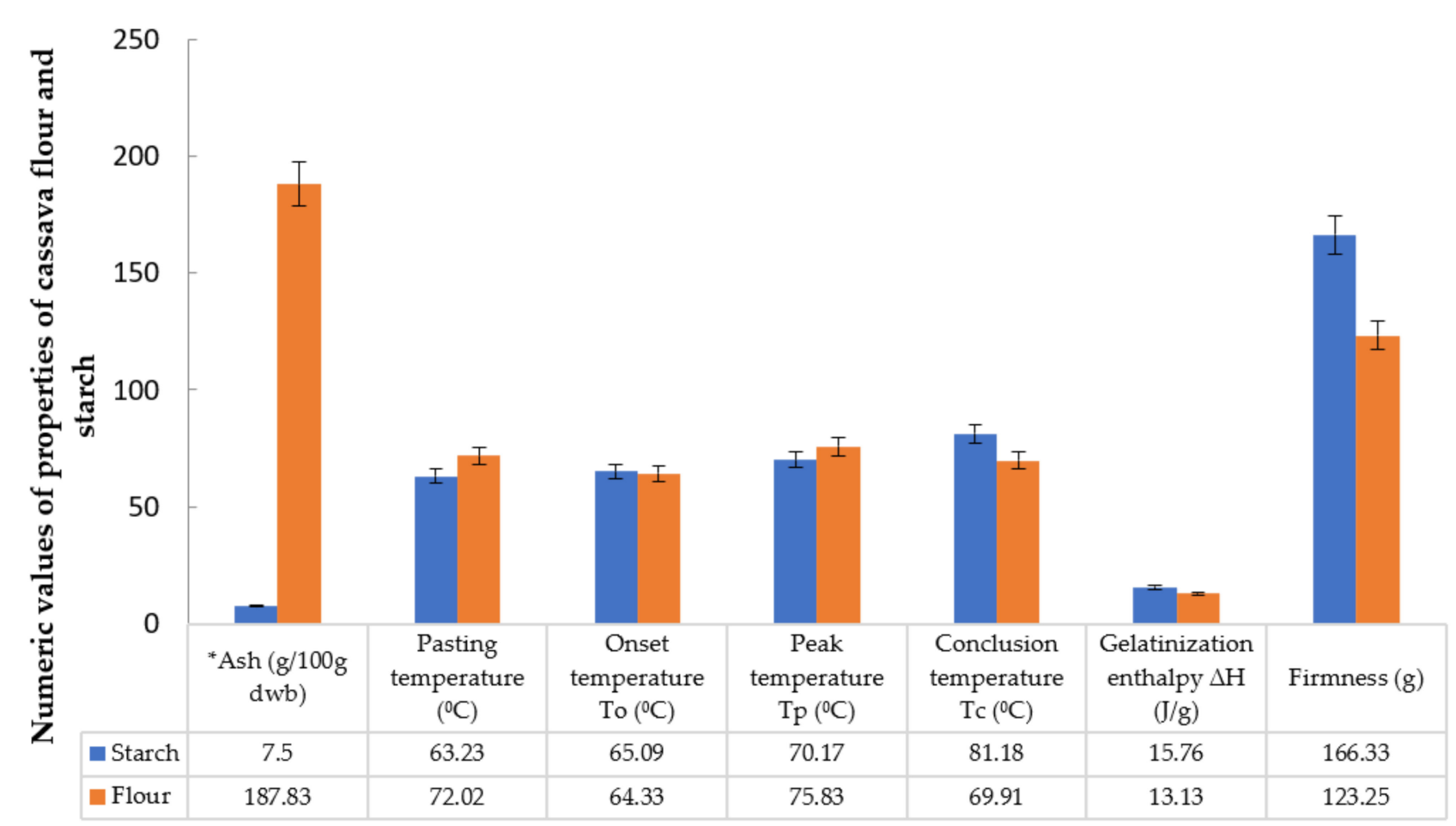

Functional properties of cassava starch and flour

- Starch $\square$ Flour

Figure 2. Functional properties of cassava starch and their corresponding flour. All values are average values obtained from 12 varieties of cassava; ${ }^{*}$ actual values in the column were multiplied by 100. Adapted from [69].

\section{Classification, Nomenclature, and Properties of Cassava Flours}

Cassava flours are broadly categorized into those fermented and unfermented [14]. Unfermented CF is white, odorless, and bland [73], while fermented CF has fermentation as one of its major processing steps, and it has a sour flavor. In most literature $[14,41,73,74]$, unfermented cassava flours are referred to as high-quality CF (HQCF); it appears white, has a low-fat content, is not sour like fermented CF, and does not give an off-odor or taste to food products. The odorless attribute is an advantageous quality of HQCF, which makes it a very suitable composite for various food products because it does not introduce a smell different from that of the original product [73]. HQCF is made within a day of harvesting the root. Mechanized techniques have been developed to reduce the time and energy involved in the process [75]. Local farmers are encouraged to adopt these newly developed modern techniques, which make the process fast and guarantee better product quality [76].

The traditional methods may take too long, and fermentation sets in mostly during dewatering and drying of grated pulps, which adversely affects the functionality of the flour as composite [9]. Most traditional cassava meals are obtained from fermented CF.

These flours are mostly consumed in the reconstituted dough form eaten with soups in most African countries. The fermented flours and their corresponding dough are given various traditional names, such as Fufu, Lafun, Agbelima, Kivunde, Kokonte, Ugali, and Wikau maombo, in different regions $[10,57,58,63,64,77-84]$. From a critical point of view, although the term high-quality may suggest higher nutritional content, it only applies to the starch content. It has been shown in the literature that HQCF has a lower nutritional value but contains a higher amount of high-quality starch than fermented CF [62]. Some authors term unfermented CF as raw [85,86], native [62], and simply dry [66]. 
There are large variations in CF due to different conditions the root is subjected to during processing [55]. These variations have given rise to various prefixes such as modified, enriched, fortified, pre-gelatinized, roasted, water group, dry group, wet-milled, and dry-milled. Terminologies vary across ethnic groups and regions. For instance, $C F$ milled directly from dried chips may be termed dry group CF [87] or dry-milled [66]. As depicted in Table 2, the proximate composition of the unmodified/native CF is different from the modified flour.

Table 2. Types of cassava flour: physicochemical composition.

\begin{tabular}{|c|c|c|c|c|c|c|c|c|c|c|c|}
\hline $\begin{array}{c}\text { Types of } \\
\text { Cassava Flour }\end{array}$ & CHO (\%) & $\begin{array}{l}\text { Protein } \\
(\%)\end{array}$ & Fat $(\%)$ & Ash (\%) & $\begin{array}{c}\text { Fiber } \\
(\%)\end{array}$ & $\begin{array}{c}\text { Moisture } \\
(\%)\end{array}$ & $\underset{(\mathrm{mg} / \mathrm{kg})}{\mathrm{HCN}}$ & $\begin{array}{l}\text { Dextrose } \\
\text { Equivalent }\end{array}$ & $\begin{array}{l}\text { Total } \\
\text { Sugars }\end{array}$ & $\begin{array}{c}\text { Water } \\
\text { Activity } \\
\left(a_{w}\right)\end{array}$ & Reference \\
\hline $\begin{array}{l}\text { Native or } \\
\text { unmodified }\end{array}$ & 82.09 & 1.14 & 0.93 & 2.30 & 2.19 & 11.49 & 7.75 & 2.00 & & & \multirow{2}{*}{ [62] } \\
\hline $\begin{array}{c}\text { Modified } \\
\text { (enzymatically) } \\
\text { Fortified }\end{array}$ & 88.80 & 2.19 & 0.78 & 1.44 & 1.60 & 5.80 & 3.88 & 2.50 & & & \\
\hline $\begin{array}{c}\text { (fermented with } \\
\text { protein } \\
\text { hydrosylates) }\end{array}$ & 85.40 & 11.26 & 0.75 & 1.51 & 1.61 & 6.44 & 2.50 & 3.30 & & & \multirow{3}{*}{ [66] } \\
\hline $\begin{array}{l}\text { Pre-gelatinized } \\
\text { Dry milled, }\end{array}$ & $64.10-75.31$ & $1.19-1.42$ & $0.38-0.60$ & $1.89-3.28$ & $\mathrm{Nd}$ & $8.46-9.76$ & - & - & - & - & \\
\hline $\begin{array}{l}\text { ungelatinized, } \\
\text { and } \\
\text { unfermented }\end{array}$ & $72.99-78.76$ & $1.31-1.98$ & $0.48-1.03$ & $2.13-3.36$ & - & $\begin{array}{l}10.57- \\
11.66\end{array}$ & - & - & - & - & \\
\hline Water group & 68.32 & 1.10 & 1.04 & 0.75 & & 8.28 & - & - & 0.42 & 0.45 & \multirow[b]{2}{*}{ [87] } \\
\hline Dry group & 76.57 & 0.52 & 0.26 & 0.83 & & 9.17 & - & - & 1.10 & 0.53 & \\
\hline
\end{tabular}

\section{Microstructure of Cassava Flour}

Microstructural analysis of CF using a scanning electron microscope (SEM) reveals that the morphology of different types of CF varied due to fermentation. The degree of hydrolysis by enzymatic modification was evident in the shape and size of the CF granules when compared to the unfermented CF. Observation of the SEM micrographs in Figure 3 shows that the unfermented CF had a smooth surface of starch granules while starch granules of modified CF (MCF) and fermented CF (FCF) were broken with rough and eroded surfaces. The size and amount of granules also decreased. This was attributed to corrosion and enzymatic hydrolysis during processing [62]. The predominant shapes of starch granules in CF are rounded, oval, and truncated, ranging from 9 to $20 \mu \mathrm{m}$ in size [71].
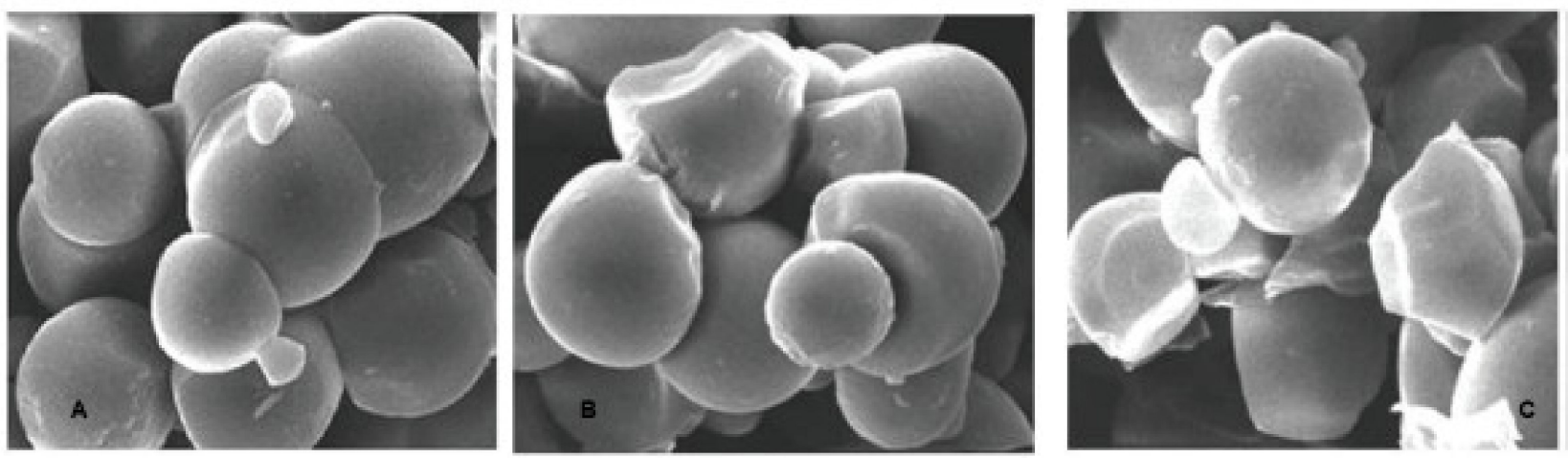

Figure 3. SEM microphotographs of cassava flour: (A) Native (unfermented); (B) Modified; (C) Fermented. Source: [62].

With the aid of High-Resolution Optical Microscopy, micrographs of CF can be obtained (Figure 4). Through an optical microscope coupled with a digital camera and application of toluidine blue dye on samples, fibers and starch granules were distinctly captured [39]. In the micrographs, it was observed that the number of starch granules was greater than the number of fibers in $\mathrm{CF}$. 


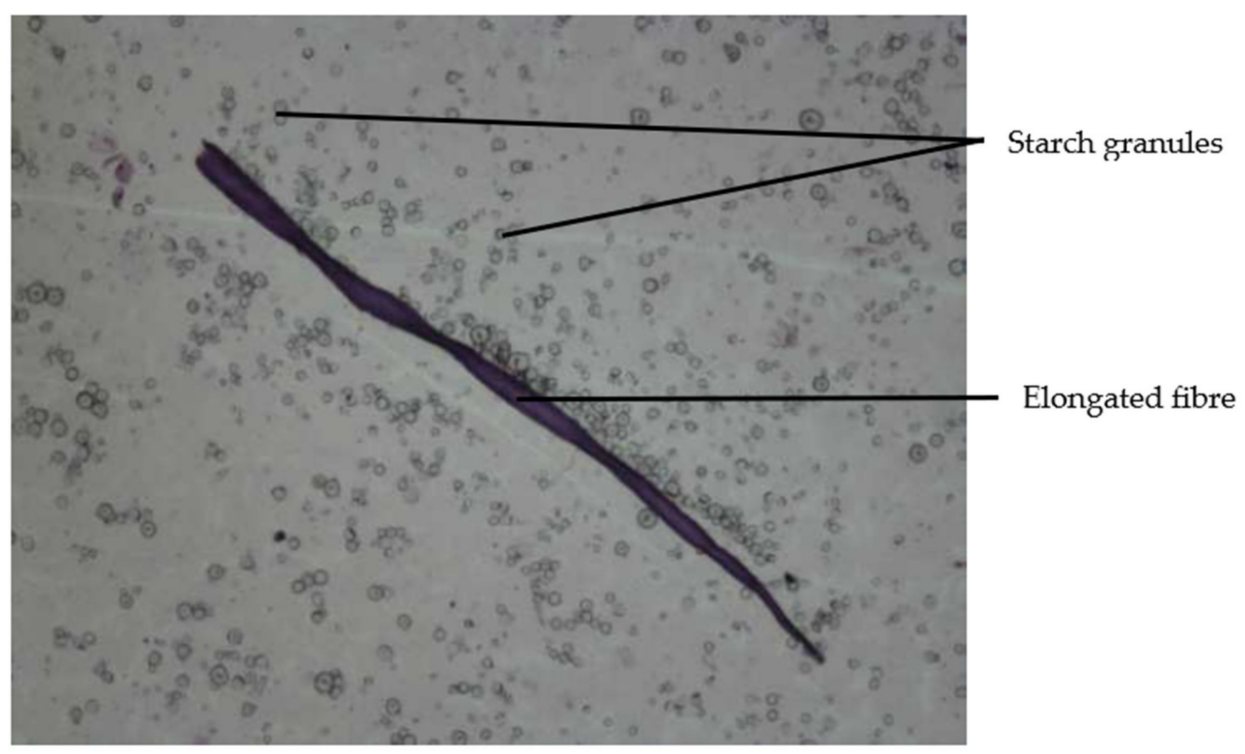

Figure 4. Micrograph of cassava flour showing longitudinally elongated fiber surrounded by starch granules. Source: [39].

\section{Effect of Processing Variables on Cassava Flour}

Various literature has shown that variety, maturity, environmental conditions, locations, and postharvest practices affect the properties of cassava $[6,45,88,89]$ and, by way of extension, the quality of its flour.

\subsection{Variety of Root}

It is recognized that the quality of flour varies with the variety of cassava from which they are processed (Table 3). An extensive study of over 670 cassava varieties grown at the IITA research farm, Nigeria, in 2000 and 2001 was evaluated for genotypic variations in cyanogenic potential and pasting properties [90]. The results showed that there were variations in the cyanide content as well as the genotype $\mathrm{x}$ year interactions on the cyanide contents. There were significant $(p<0.05)$ genotypic variations in all the pasting properties except pasting temperature and peak time in 2001. On this basis, the clones were screened and characterized for food, feed, and industrial applications.

The evaluation of the physicochemical and pasting properties of CF processed from 31 different varieties was conducted by Aryee et al. [53]. These varieties were not well adapted because of their poor cooking quality and high cyanogenic potential. Their results showed that starch content ranged from 67.92 to $88.11 \%$. The amylose content of CF varied from 10.9 to $44.3 \%$. The CF had low swelling power values ranging from 5.87 to 13.48 . Water binding capacity varied from 113.66 to $201.99 \%$. Gelatinization temperature was in the range of $66.8-70.4{ }^{\circ} \mathrm{C}$, with peak temperatures varying between 73.1 and $84.5^{\circ} \mathrm{C}$. The cyanogenic potential (CNp) ranged from 0.58 to $20.0 \mathrm{mg} \mathrm{HCN}$ per $100 \mathrm{~g}$ of dry weight. From the data obtained, the authors recommended that these varieties could be used for other purposes such as starch production, glucose, adhesives, fuel alcohol, animal feed, and other industrial uses.

Charoenkul et al. [69] studied the physicochemical characteristics of 12 cassava varieties with low cyanide content from Thailand and reported that all the flours showed wide variation in their properties. Five varieties of cassava, namely, Lakan 1, Sultan 6, Sultan 7, Rajah 2, and Rajah 4, bred and cultivated in the Philippines, were researched by Murayama et al. [66]. The dry and pre-gelatinized flours from these varieties displayed different properties; however, the Lakan 1, Sultan 6, and Sultan 7 varieties were found to be more suitable for pre-gelatinization, mostly due to the greater retention of chemical components. The attributes of $\mathrm{CF}$ during storage can be significantly influenced by cultivars; hence, proper selection of cultivars is recommended [67]. The study of Eleazu and 
Eleazu [91] indicates that some cassava cultivars of the yellow varieties may have dual utility both for human consumption and for industrial purposes, while the white variety may be confined to domestic use. Pictures of cross-sections of white and yellow varieties are shown in Figure 5. It can be deduced from these studies that although cassava may be used for diverse applications, each variety of cassava best suits a particular application, and depending on the variety and end-use, the right processing condition should be applied.
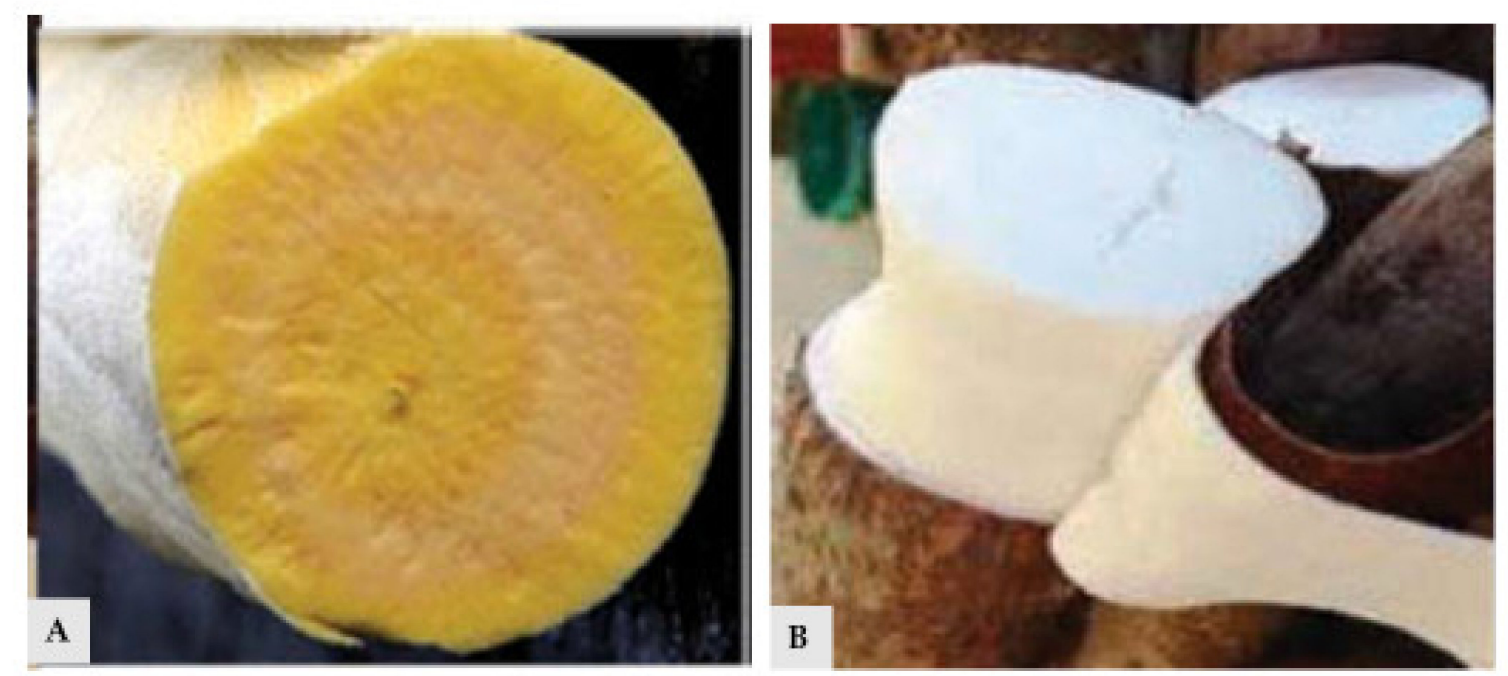

Figure 5. Pictures of cross-section of cassava root. (A) Pro-vitamin A cassava variety UMUCASS 36. (B) White cassava variety TME 419. Source: [67].

\subsection{Pre-Gelatinization}

Pre-gelatinization is a process that gives starches the ability to develop viscosity without the need for heat. Pre-gelatinization of CF may be achieved by cooking or steaming the roots before drying and milling. During the application of heat in the presence of water, the starch in the root gelatinizes. An alternative to supplying cassava for industrial use is transforming the roots into precooked $\mathrm{CF}$, which can then be used as a raw material for processing high value-added products such as cassava dough, croquette, fried chips, or snacks. Murayama et al. [66] investigated the effect of pre-gelatinization on the proximate, mineral, and soluble sugar composition, starch, pasting and thermal properties, solubility, swelling power, and particle size distribution of CF. The pre-gelatinized flours showed significantly lower values for viscosity, pasting temperature, and $\alpha$-amylase activity than their corresponding ungelatinized flours. The use of a differential scanning calorimeter revealed a complete amorphization of the starch contained, and it was deduced that pregelatinization causes an increase in the fructose, glucose, amylose content, damaged starch, and mean particle size compared to the corresponding flours that were not gelatinized. From the study, it could be inferred that pre-gelatinization has a great potential for textural and structural improvement by reduction of starch retrogradation in bakery products. Rodriguez-Sandoval et al. $[65,93]$ studied the effects of the cooking (steaming and boiling) method on the retrogradation of starch in flour, and it was reported that CF pre-gelatinized by steaming showed an increase in starch retrogradation, which may be as a result of higher amylose content. 
Table 3. Studies on varietal differences in cassava flour (CF).

\begin{tabular}{|c|c|c|c|c|}
\hline $\begin{array}{l}\text { Number of } \\
\text { Varieties }\end{array}$ & Description of Varieties & Source/Country & $\begin{array}{l}\text { Difference in CF Properties Associated with } \\
\text { Varieties }\end{array}$ & References \\
\hline 3 & Local varieties & Accra, Ghana & $\begin{array}{c}\text { No significant difference in acidity, moisture, and } \\
\text { starch content } \\
\text { Difference in pasting characteristics, water-binding } \\
\text { capacity, and swelling power }\end{array}$ & [42] \\
\hline 2 & White and yellow & $\begin{array}{c}\text { National Root Crops Research } \\
\text { Institute (NRCRI), Umudike, } \\
\text { Nigeria }\end{array}$ & $\begin{array}{l}\text { Significant differences in proximate composition and } \\
\text { color attributes; exhibited slightly different } \\
\text { hygroscopic behaviors during storage }\end{array}$ & {$[67,68]$} \\
\hline 17 & Bitter yellow & State of Bahia, Brazil & $\begin{array}{l}\text { Variation in total carotenoid content } \\
\text { Higher residual cyanide and quantities of reducing }\end{array}$ & [92] \\
\hline 6 & New elite yellow and white & NRCRI, Umudike, Nigeria & $\begin{array}{l}\text { sugar and carotenoid in yellow varieties compared to } \\
\text { the white }\end{array}$ & [91] \\
\hline 31 & 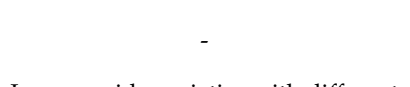 & $\begin{array}{l}\text { Crop Research Institute (CRI), } \\
\text { Ghana }\end{array}$ & $\begin{array}{l}\text { A wide variance in cyanide content, starch content, } \\
\text { swelling power, water-binding capacity and } \\
\text { gelatinization temperatures }\end{array}$ & [53] \\
\hline 12 & $\begin{array}{l}\text { Low cyanide varieties with different } \\
\text { cooked textures: mealy, firm and } \\
\text { mealy and firm }\end{array}$ & $\begin{array}{l}\text { Rayong Field Crops Research } \\
\text { Center, Thailand }\end{array}$ & Wide variation in pasting characteristics & [69] \\
\hline 11 & Different genotypes & IITA, Ibadan, Nigeria & Variation in total dietary fiber and viscosity profile & [71] \\
\hline 5 & $\begin{array}{l}\text { Varieties developed in the } \\
\text { Philippines }\end{array}$ & Philippines & $\begin{array}{l}\text { Slight significant difference in soluble sugar, } \\
\text { proximate, and mineral composition }\end{array}$ & {$[66]$} \\
\hline 2 & Red and white landraces & $\begin{array}{l}\text { Agricultural Research } \\
\text { Council, South Africa }\end{array}$ & Significant difference in cyanide content & {$[44]$} \\
\hline
\end{tabular}

\subsection{Fermentation}

The positive roles that microorganisms play during fermentation include detoxification, flavor development, biological enrichment, product preservation, and a decrease in cooking time [94]. Fermentation, either naturally or with selective inoculation of microorganisms, has been extensively used to enhance the nutrient potentials of cassava for human consumption [95]. Akindahunsi et al. [56] fermented cassava pulp with Rhizopus oryzae (at room temperature for three days), which caused a $97 \%$ increase in the protein content of the flour, a 5\% decrease in the carbohydrate content, and no considerable increase in the fat, ash and lipid content. The level of antinutrients, tannin, and cyanide, except phytate, was considerably low. The level of phytate increased, and the mechanism of this increase could not be ascertained. It was inferred that this increase might be due to the conversion of some plant metabolite or nutrient content, in the solution, to phytate or phytate-like products. Phytate can chelate divalent cationic minerals such as $\mathrm{Ca}, \mathrm{Fe}, \mathrm{Mg}$, and $\mathrm{Zn}$, therefore, impairing their bioavailability. However, phytate functions as an antioxidant, inhibiting the formation of free radicals, by sequestering iron [89]. A similar trend was reported by Oboh and Akindahunsi [59] in the use of Saccharomyces cerevisiae for fermenting cassava, which increased the protein and fat content of the flour. There was no significant change in the tannin, crude fiber, or ash content of the flour, but there was a significant decrease in the cyanide, carbohydrate, and mineral content. The chelating activity of phytate may be responsible for the decrease in mineral content.

Fermentation with these microorganisms (R. oryzae and S. cerevisiae) greatly influences the chemical composition of CF positively by increasing the protein level of CF and at the same time reducing the level of some antinutrients, specifically total cyanide. These microorganisms (R. oryzae and S. cerevisiae) could efficiently improve the nutritional content of $C F$; however, the knowledge of secretion of some harmful metabolites associated with microbial activities [96] prompted further research by Oboh and Akindahunsi [60] on the nutritional and toxicology of CF fermented with S. cerevisiae. They reported high digestibility and no negative hematological effect. However, a significant rise in pyruvate transaminase and serum glutamate oxaloacetate transaminase activities in the serum were observed, which indicates hepatotoxicity and cardiotoxicity. Upon further pathological investigation, the spleen showed some dark red coloration, while the liver had some necrotic lesions $[26,60,61]$.

\subsection{Drying and Processing Temperatures}

Murayama et al. [66] dried chipped cassava roots in a hot air oven at $40^{\circ} \mathrm{C}$; however, the duration it took to dry was not mentioned. Rodriguez-Sandoval et al. [65] incorpo- 
rated resting time after precooking into the stored fresh cassava chips at 5 and $-20{ }^{\circ} \mathrm{C}$ before drying and milling. The flour stored at $-20^{\circ} \mathrm{C}$ showed no significant differences in the retrogradation of starch. Rodriguez-Sandoval et al. [93] reported that the temperature during storage was the most important factor affecting the textural properties of cassava dough. Omolola et al. [97] reported that the use of optimum duration and temperature of drying of cassava chips is a key factor in preserving the color and thermal properties of CF. Three traditional processing methods (sun-drying, roasting, and fermentation before sun-drying) were used to produce three types of CF in a study conducted by Eduardo et al. [98]. Their findings inferred that the sun-drying method gave a higher yield than roasting. However, upon use as a composite in bread making, the roasted CF had a significantly higher volume of bread compared with sun-dried or fermented CF.

\subsection{Milling and Sieving}

In whatever order the process flow takes, milling precedes sieving [98]. Sieving is usually the last step in the flow chart of processing CF before packaging for storage. Milling and sieving are both physical and mechanical processing factors that influence the yield and particle size of CF [46]. However, these processing steps are not given as much research attention as others; hence, there appears to be a dearth of information on the yield, particle size distribution, and average particle size of different types of CFs. The fineness of CF is a function of the efficiency and type of milling machine used [99], and it is also controlled by the attritions on the screen of the mechanical mill. One $\mathrm{kg}$ sample of dried cassava chips milled using a pin, hammer, attrition, and mortar mills gave percentage flour recoveries of $96,87,75$, and 62 , respectively [46]. To some extent, the fiber content of cassava makes it difficult to fine mill; thus, its average particle size $(228 \mu \mathrm{m})$ and most frequently occurring particle size $(256 \mu \mathrm{m})$ was significantly higher than that of wheat flour [99]. Chisenga et al. [100] reported the average particle sizes of CF in the ranges 250.44-334.34, 103.76-142.42, 90.59-133.19, 63.09-114.75, and 35.56-48.52 $\mu \mathrm{m}$ for sieves $38-425 \mu \mathrm{m}$.

Some processors do not sieve after milling, but sieving of the flour gives a betterquality product [74]. According to Sahin and Sumnu [101], the average particle size of various floury foods depends not only on the cell structure but also on the degree of processing that the material undergoes. The use of aperture sized sieves of $180 \mu \mathrm{m}$ was reported by Murayama et al. [66], while Eduardo et al. [98] reported a lower size of $125 \mu \mathrm{m}$, which is within the range $(100-150 \mu \mathrm{m})$ reported by Lépiz-Aguilar et al. [102]. Aperture sizes of 50 and $550 \mu \mathrm{m}$ were used to sieve CF in the study of Adesina and Bolaji [46]. In the molding of thermoplastic material from CF, the particle size (ranging from 250 to 600 $\mu \mathrm{m}$ ) was included as one of the design factors by Navia and Villada [39]. They established, with the aid of response surface analysis, that the molded material with the highest tensile strength was that with the $600 \mu \mathrm{m}$ particle size. Sieving is an important step in processing because it determines the particle size, an important physical property, of the flour, which further influences the functional properties of the flour and the subsequent products from them [99]. The particle size of CF can significantly affect its hydrothermal behavior [100].

\subsection{Fortification}

Due to the high carbohydrate content of CF, fortification is completed to improve the nutritional quality. The addition of flours of legumes and/ or cereal grains to CF is a means of fortification [103]. Co-processing the root with fermented protein hydrolysates not only increased the protein content but also decreased the cyanide content of the fortified CF. There was a significant increase in the viscosity when the level of protein hydrolysates was increased [62]. Another form of fortification is the addition of enzymes such as Termamyl, a thermostable $\alpha$-amylase, to moistened CF to produce malted CF. The addition of Termamyl to CF resulted in increased hardness of muffins and biscuits baked from it [104]. 


\subsection{Packaging Materials and Storage Conditions}

Retaining the quality of $\mathrm{CF}$ during storage is a critical factor that directly affects the quality of the flour at end-use. During storage, flours may be packed in low-density polyethylene (LDPE) bags, plastic buckets, sack, jute, and paper bags [105]. The appropriate packaging material, temperature, and relative humidity are critical for the retention of product quality [106]. The use of improper packaging materials could lead to a reduction in the quality and shelf life of flour. $\mathrm{CF}$ is best stored at ambient temperature since storage in refrigeration temperature causes an increase in microbial count [67]. During the storage of $\mathrm{CF}$, the whiteness, cyanide, and total carotenoids content decrease in the course of transportation and sales. Opara et al. [68] investigated the effect of plastic buckets, LPDE, and paper bags on the physicochemical and microbial stability of flour of two cassava cultivars under the same temperature and humidity $\left(23 \pm 2{ }^{\circ} \mathrm{C}\right.$ and $60 \%$ relative humidity) for 12 weeks. Total color difference $(\Delta \mathrm{E})$ increased with storage time for flours packed in plastic buckets, giving the least color change. Total carotenoid decreased as storage time increased in all packaging materials, but flour packed in plastic had the highest total carotenoid retention. Cassava flour in a paper bag had the lowest microbial count for the total aerobic mesophilic bacteria and fungi.

\section{Assessment of Microbial Safety}

Cassava flour is majorly produced in artisanal units, which do not adhere to the rules of food safety [107]. The challenge of standardizing small-scale processing is that the processors have various target flour in mind, and the desired end product differs across ethnicity and regions. One constraint in the commercialization of locally produced cassava products is variation in the quality of the products amongst processors and processing batches of the same processor [58,108]. The standard Codex 176-1989; EAS 740:2010 microbiological limits for CF are the total viable count of $5.00 \log \mathrm{cfu} \mathrm{g}^{-1}$, S. aureus limits $2.00 \log \mathrm{cfu} \mathrm{g}^{-1}$, and zero coliform count. However, the result of the studies $[58,81,107,109]$ indicates that some of the microbial limits were exceeded. Although CF is not in its readyto-eat form, it is worrisome that a very high percentage of the CF samples analyzed were contaminated with very high microbial counts. However, CF samples prepared in the laboratory had a low microbial load compared to samples collected from various processing sites and markets [81]. This implies that although the handling and processing practices of cassava roots expose them to microbial contamination [109], if more hygienic measures are taken, contamination can be avoided, and the safety of the product can be guaranteed.

\section{Application of Cassava Flour in Food and Industrial Processes}

Postharvest loss of rapidly deteriorating cassava root may be curtailed by processing the tuber into flour. CF can be used as representative of the edible portion of the fresh root because it has the same component as the root, except the moisture [69]. CF is one of the easiest food products from cassava obtained from milling the dried root. Compared to other food products of cassava, such as starch, gari, and cassava rice, the processing of $\mathrm{CF}$ is less rigorous, which lowers the overall production cost [36]. CF is a major product of cassava; for instance, about $80 \%$ of cassava root produced in Brazil is designated for CF [92,107], and almost 70\% of cassava root in Mozambique is used in CF production [110]. The agronomic trait of cassava promotes the low cost and all-year-round availability of its flour.

The composite flour program was initiated by FAO in the year 1964, conceived with the primary aim of utilizing locally available raw materials in the production of bakery products in countries that could not meet their wheat requirements [111]. This program must have contributed to the remarkable increase in the research attention given to cassava in the past few decades, especially in African countries. Eriksson [42] stated that the increase in the price of wheat on the global market had promoted interest in utilizing local sources of flour to reduce dependence on wheat and improve the livelihood of local farmers. Cassava flour is now being considered as an alternative to wheat flour. The IITA 
and the International Centre for Tropical Agriculture (CIAT) have been at the forefront of enhancing cassava productivity and the development of improved cultivars $[8,14,112]$.

In addition to availability and low cost, $\mathrm{CF}$ is gluten-free, and products of this attribute are advantageous, which makes it highly recommended in the diet of celiac patients. Celiac patients struggle with an autoimmune complex that affects the bowel after ingestion of grains or cereals such as wheat and rye that contain gluten $[113,114]$. Cassava flour has been reported to be a good source (1.93-2.21\%) of resistant starch [55], which has the same impact on human health as fiber-enriched foods. The production of short-chain fatty acids due to the fermentation of resistant starches by microorganisms in the colon confers on consumers the benefit of mitigating ailments such as diabetes, cardiovascular diseases, obesity, and osteoporosis [115].

Good quality CF can be processed into various flour-based food products and used as composite flour (Table 4). Different researchers have developed a variety of foods using CF (Table 4), such as bread [116], biscuits [117], noodles [118], and other confectionaries [119], both as composite and the base flour. The use of $\mathrm{CF}$ is a convenient alternative to wheat for producing a gluten-free product and developing bio-fortified and fortified foods $[40,120]$. Cassava flour has the potential to enhance food security, economic development, and consumers' health [121-123].

Table 4. Application of cassava flour (CF) in various flour-based food products.

\begin{tabular}{|c|c|c|c|c|}
\hline Flour Composition & Food Product & $\begin{array}{c}\text { Level of CF } \\
\text { Inclusion (\%) }\end{array}$ & Key Findings & References \\
\hline $\begin{array}{l}\text { Pro-vitamin A CF and } \\
\text { wheat flour }\end{array}$ & Biscuit & $10-40$ & $\begin{array}{c}\text { Fat and protein contents of biscuit } \\
\text { decreased with increasing proportions of } \\
\text { pro-vitamin A CF. Overall acceptability of } \\
10 \% \text { CF inclusion was same as } 100 \% \text { wheat } \\
\text { flour. }\end{array}$ & [117] \\
\hline $\begin{array}{l}\text { CF with improvers } \\
\text { (ascorbic acid, sodium } \\
\text { metabisulphite, sorbic } \\
\text { acid, and soy flour) }\end{array}$ & $\begin{array}{l}\text { Whole cassava } \\
\text { biscuit }\end{array}$ & 100 & $\begin{array}{l}\text { Slight decrease in mixing time, extrusion } \\
\text { time, length, and width of the biscuits. }\end{array}$ & [124] \\
\hline $\mathrm{CF}$ and soybean flour & Biscuit & 50 & $\begin{array}{l}\text { No significant differences in color, texture, } \\
\text { flavor, taste, and overall acceptability of the } \\
\text { flour-blend biscuits. }\end{array}$ & {$[125,126]$} \\
\hline $\begin{array}{l}\text { CF (roasted, sun-dried, } \\
\text { and fermented), wheat, } \\
\text { and maize }\end{array}$ & Bread & $20-40$ & $\begin{array}{l}\text { Type of CF influenced product quality. For } \\
\text { example, roasted CF yielded the highest } \\
\text { bread volume. }\end{array}$ & [98] \\
\hline (25) & Noodles & 100 & $\begin{array}{c}\text { CF could serve as a good substitute for } \\
\text { wheat flour in noodle production and } \\
\text { utilization. }\end{array}$ & [127] \\
\hline $\begin{array}{l}\text { HQCF and soybean; } \\
\text { HQCF and cowpea }\end{array}$ & Fried snack & 50 & $\begin{array}{c}\text { Soy variant of the snack contained } \\
\text { significantly higher protein than the } \\
\text { cowpea variant. Product was acceptable to } \\
\text { panelist. }\end{array}$ & [128] \\
\hline $\begin{array}{l}\text { Malted and } \\
\text { pre-gelatinized CF with } \\
\text { cereal and or legume bran }\end{array}$ & Muffins and biscuits & 70 & $\begin{array}{l}\text { Pre-gelatinization and malting improved } \\
\text { the functionality of CF. }\end{array}$ & [104] \\
\hline $\begin{array}{l}\text { HQCF, acetylated cassava } \\
\text { starch and wheatHQCF, } \\
\text { acetylated cassava starch } \\
\text { and wheat }\end{array}$ & Bread & $7-32$ & $\begin{array}{l}\text { Increasing component of CF in the blends } \\
\text { was found to mask the undesirable } \\
\text { influence of acetylated starch on the } \\
\text { functional and physical properties of bread. }\end{array}$ & [129] \\
\hline $\begin{array}{l}\text { CF, wheat, maize, and } \\
\text { cowpea }\end{array}$ & Bread & $5-30$ & $\begin{array}{l}\text { Bread with up to } 10 \% \text { CF inclusion was } \\
\text { acceptable by sensory panelist. }\end{array}$ & [99] \\
\hline $\begin{array}{l}\text { CF, wheat, and malted } \\
\text { soybean }\end{array}$ & Bread & $10-90$ & $\begin{array}{l}\text { The loaf volume, specific loaf volume, and } \\
\text { oven spring reduced appreciably as the } \\
\text { substitution with CF increased. It was } \\
\text { recommended that CF be substituted for } \\
\text { wheat flour up to } 30 \% \text {, using malted } \\
\text { soybean flour as an improver. } \\
\text { CF can serve as a good substitute for wheat } \\
\text { flour in bread making. }\end{array}$ & [131-141] \\
\hline
\end{tabular}


Table 4. Cont.

\begin{tabular}{|c|c|c|c|c|}
\hline Flour Composition & Food Product & $\begin{array}{l}\text { Level of CF } \\
\text { Inclusion (\%) }\end{array}$ & Key Findings & References \\
\hline CF and wheat & Noodles & 50-100 & $\begin{array}{l}\text { Cassava-wheat composite flour noodles } \\
\text { showed promising results, with their } \\
\text { acceptability closely following the } \\
\text { acceptability of commercial noodles used } \\
\text { as control. }\end{array}$ & {$[118,142]$} \\
\hline $\begin{array}{l}\text { Unfermented, dry milled } \\
\qquad \text { CF and maize }\end{array}$ & $\begin{array}{l}\text { Tuwo (a } \\
\text { non-fermented } \\
\text { maize-based } \\
\text { dumpling) }\end{array}$ & $5-30$ & $\begin{array}{l}\text { Cohesiveness indices increased with an } \\
\text { increase in the quantity of CF. }\end{array}$ & [143] \\
\hline HQCF and soy flour & $\begin{array}{l}\text { Ginger-flavoured } \\
\text { soy-cassava biscuit }\end{array}$ & $60-100$ & $\begin{array}{l}\text { Sensory evaluation confirmed positive } \\
\text { acceptability of the product. }\end{array}$ & [144] \\
\hline $\begin{array}{l}\mathrm{CF} \text {, rice flour, extruded } \\
\text { protein concentrate, and } \\
\text { pumpkin powder }\end{array}$ & $\begin{array}{l}\text { Gluten-free } \\
\text { flatbread and } \\
\text { biscuits }\end{array}$ & Approximately 50 & $\begin{array}{c}\text { CF could serve as base flour for gluten-free } \\
\text { baked products. }\end{array}$ & [145] \\
\hline CF, wheat, and soy flour & Biscuit & $10-70$ & $\begin{array}{l}\text { No significant difference in overall } \\
\text { acceptability between biscuit from the } \\
\text { control (100\% wheat flour) and the } \\
\text { composite flours of up to } 40 \% \text { cassava } \\
\text { substitution level. }\end{array}$ & [146] \\
\hline CF, Bambara, and wheat & $\begin{array}{c}\text { Biscuit } \\
\text { Cocoa-powder- }\end{array}$ & $35-90$ & Use of $100 \%$ CF could not form dough for & [147] \\
\hline CF and cocoa powder & $\begin{array}{l}\text { based } \\
\text { biscuits }\end{array}$ & 20-100 & $\begin{array}{l}\text { biscuit production. Biscuits with } 20 \% \text { CF } \\
\text { were found to be most acceptable. } \\
\text { The flour mix }(1: 1: 1) \text { produced gluten-free }\end{array}$ & [148] \\
\hline CF, pumpkin, and potato & Gluten-free cake & Approximately 35 & $\begin{array}{l}\text { cake samples with good nutritional values, } \\
\text { cake volume, high freshness, and } \\
\text { acceptable sensory properties. }\end{array}$ & [149] \\
\hline CF, wheat, and cowpea & Cookies & $35-80$ & $\begin{array}{l}\text { Cookies from composite flours were not } \\
\text { significantly }(p>0.05) \text { different from the } \\
\text { control in overall acceptability. }\end{array}$ & [150] \\
\hline
\end{tabular}

\section{Conclusions}

The studies reviewed show that the processing variables, which include variety, fermentation, fortification, pre-gelatinization, sieving, temperature, packaging, and storage conditions, influence the quality of the CF. It can also be deduced that specific varietal selection and manipulation of processing conditions is important to produce different cassava flours suitable for specific purposes. The quest of making CF more suitable for baking may be achieved by objectively controlling the modification process of $\mathrm{CF}$, such as pre-gelatinization, temperature, milling, and sieving to become wheat-like. This is a promising means to advance the utilization of CF globally. The ultimate concern of product safety has to be guaranteed by adhering to safety guidelines during processing as well as proper packaging and storage.

Author Contributions: Conceptualization, E.O.U., T.A.A., and A.I.O.J.; writing-original draft preparation, E.O.U.; writing — review and editing, E.O.U., T.A.A., and A.I.O.J. All authors have read and agreed to the published version of the manuscript.

Funding: The authors acknowledge the University of Venda, Research and Publication Committee, for funding the study under project number SARDF/18/FST/04; LEAP Agri Research Cooperation Project-115578 (SARDF/18/FST/06); and the National Research Foundation of South Africa, Grant Number 119811 (TAA).

Institutional Review Board Statement: Not applicable.

Informed Consent Statement: Not applicable.

Data Availability Statement: The data presented in this study are openly available at the referenced numbers.

Conflicts of Interest: The authors declare no conflict of interest. 


\section{References}

1. Burrell, M. Starch: The need for improved quality or quantity-An overview. J. Exp. Bot. 2003, 54, 451-456. [CrossRef] [PubMed]

2. Olsen, K.M.; Schaal, B.A. Microsatellite variation in cassava (Manihot esculenta, Euphorbiaceae) and its wild relatives: Further evidence for a southern Amazonian origin of domestication. Am. J. Bot. 2001, 88, 131-142. [CrossRef]

3. Nhassico, D.; Muquingue, H.; Cliff, J.; Cumbana, A.; Bradbury, J.H. Rising African cassava production, diseases due to high cyanide intake and control measures. J. Sci. Food Agric. 2008, 88, 2043-2049. [CrossRef]

4. Haggblade, S.; Djurfeldt, A.A.; Nyirenda, D.B.; Lodin, J.B.; Brimer, L.; Chiona, M.; Chitundu, M.; Chiwona-Karltun, L.; Cuambe, C.; Dolislager, M. Cassava commercialization in Southeastern Africa. J. Agribus. Dev. Emerg. Econ. 2012. [CrossRef]

5. Zhu, F. Composition, structure, physicochemical properties, and modifications of cassava starch. Carbohydr. Polym. 2015, 122, 456-480. [CrossRef] [PubMed]

6. Tewe, O.O.; Lutaladio, N. Cassava for Livestock Feed in Sub-Saharan Africa. 2004. Available online: https://agris.fao.org/agrissearch/search.do?recordID=XF2015041975 (accessed on 30 September 2020).

7. Aloys, N.; Hui Ming, Z. Traditional cassava foods in Burundi-A review. Food Rev. Int. 2006, 22, 1-27. [CrossRef]

8. Montagnac, J.A.; Davis, C.R.; Tanumihardjo, S.A. Nutritional value of cassava for use as a staple food and recent advances for improvement. Compr. Rev. Food Sci. Food Saf. 2009, 8, 181-194. [PubMed]

9. Falade, K.O.; Akingbala, J.O. Utilization of cassava for food. Food Rev. Int. 2010, 27, 51-83. [CrossRef]

10. Omodamiro, R.; Oti, E.; Etudaiye, H.; Egesi, C.; Olasanmi, B.; Ukpabi, U. Production of fufu from yellow cassava roots using the odourless flour technique and the traditional method: Evaluation of carotenoids retention in the fufu. Adv. Appl. Sci. Res. 2012, 3, 2566-2572.

11. Westby, A. Cassava utilization, storage and small-scale processing. Cassava: Biol. Prod. Util. 2002, 281-300. [CrossRef]

12. Sánchez, T.; Chávez, A.L.; Ceballos, H.; Rodriguez-Amaya, D.B.; Nestel, P.; Ishitani, M. Reduction or delay of post-harvest physiological deterioration in cassava roots with higher carotenoid content. J. Sci. Food Agric. 2006, 86, 634-639. [CrossRef]

13. Udoro, E.; Gbadamosi, O.; Taiwo, K. Studies on the production and utilization of dried cassava chips as human food. In Using Food Science and Technology to Improve Nutrition and Promote National Development; International Union of Food Science \& Technology: Guelph, ON, Canada, 2008.

14. Dziedzoave, N.T.; Abass, A.B.; Amoa-Awua, W.K.; Sablah, M. Quality Management Manual for Production of High Quality Cassava Flour; IITA: Ibadan, Nigeria, 2006.

15. IITA. Released Cassava Varieties in Nigeria. Available online: https://seedtracker.org/cassava/index.php/released-cassavavarieties-in-nigeria/ (accessed on 22 July 2021).

16. Gil Llanos, J.L.; Buitrago, A.J.A. La yuca en la alimentación animal. In La yuca en el Tercer Milenio: Sistemas Modernos de Producción, Procesamiento, Utilización y Comercialización; CIAT: Cali, Columbi, 2002.

17. Rojas, C.C.C.; Nair, B.; Herbas, A.; Bergenståhl, B. Simultaneous determination of glucose, maltose and sucrose in starch of six varieties of cassava. Rev. Boliv. De Química 2006, 23, 18-23.

18. Charles, A.; Sriroth, K.; Huang, T. Proximate composition, mineral contents, hydrogen cyanide and phytic acid of 5 cassava genotypes. Food Chem. 2005, 92, 615-620. [CrossRef]

19. Otache, M.A.; Agbajor, G.K.; Akpovona, A.E.; Ogoh, B. Quantitative Determination of Sugars in Three Varieties of Cassava Pulp. Asian J. Chem. Sci. 2017, 3, 1-8. [CrossRef]

20. McMahon, J.M.; White, W.L.; Sayre, R.T. Cyanogenesis in cassava (Manihot esculenta Crantz). J. Exp. Bot. 1995, 46, 731-741. [CrossRef]

21. Burns, A.E.; Bradbury, J.H.; Cavagnaro, T.R.; Gleadow, R.M. Total cyanide content of cassava food products in Australia. J. Food Compos. Anal. 2012, 25, 79-82. [CrossRef]

22. Chiwona-Karltun, T.T.; Mkumbira, M.J.; Gebre-Medhin, H.; Rosling, L. Low dietary cyanogen exposure from frequent consumption of potentially toxic cassava in Malawi. Int. J. Food Sci. Nutr. 2000, 51, 33-43. [CrossRef] [PubMed]

23. Ellen, R.F.; Soselisa, H.L. A comparative study of the socio-ecological concomitants of cassava (Manihot esculenta Crantz): Diversity, local knowledge and management in eastern Indonesia. Ethnobot. Res. Appl. 2012, 10, 15-35. [CrossRef]

24. Montagnac, J.A.; Davis, C.R.; Tanumihardjo, S.A. Processing techniques to reduce toxicity and antinutrients of cassava for use as a staple food. Compr. Rev. Food Sci. Food Saf. 2009, 8, 17-27. [CrossRef]

25. Ebuehi, O.; Babalola, O.; Ahmed, Z. Phytochemical, nutritive and anti-nutritive composition of cassava (Manihot esculenta L) tubers and leaves. Niger. Food J. 2005, 23, 40-46. [CrossRef]

26. Oboh, G.; Elusiyan, C. Changes in the nutrient and anti-nutrient content of micro-fungi fermented cassava flour produced from low-and medium-cyanide variety of cassava tubers. Afr. J. Biotechnol. 2007, 6, 2150-2157. [CrossRef]

27. Sowmyapriya, S.; Kalarani, M.; Jeyakumar, P.; Kennedy, Z.J.; Velmurugan, M.; Arumugam, T. Assessment of biochemical changes during postharvest physiological deterioration in cassava tubers. Int. J. Pure Appl. Biosci. 2017, 5, 732-739. [CrossRef]

28. Salcedo, A.; Siritunga, D. Insights into the physiological, biochemical and molecular basis of postharvest deterioration in cassava (Manihot esculenta) roots. J. Exp. Agric. Int. 2011, 414-431. [CrossRef]

29. Qin, Y.; Djabou, A.S.M.; An, F.; Li, K.; Li, Z.; Yang, L.; Wang, X.; Chen, S. Proteomic analysis of injured storage roots in cassava (Manihot esculenta Crantz) under postharvest physiological deterioration. PLoS ONE 2017, 12, e0174238. [CrossRef]

30. Atieno, L.; Owino, W.; Ateka, E.M.; Ambuko, J. Effect of Surface Coatings on the Shelf life and Quality of Cassava. J. Food Res. 2018, 7, 46-60. 
31. Reilly, K.; Bernal, D.; Cortés, D.F.; Gómez-Vásquez, R.; Tohme, J.; Beeching, J.R. Towards identifying the full set of genes expressed during cassava post-harvest physiological deterioration. Plant Mol. Biol. 2007, 64, 187-203. [CrossRef]

32. Reilly, K.; Gómez-Vásquez, R.; Buschmann, H.; Tohme, J.; Beeching, J.R. Oxidative stress responses during cassava post-harvest physiological deterioration. Plant Mol. Biol. 2003, 53, 669-685. [CrossRef]

33. Reilly, K.; Han, Y.; Tohme, J.; Beeching, J.R. Isolation and characterisation of a cassava catalase expressed during post-harvest physiological deterioration. Biochim. Et Biophys. Acta (BBA)-Gene Struct. Expr. 2001, 1518, 317-323. [CrossRef]

34. Morante, N.; Sánchez, T.; Ceballos, H.; Calle, F.; Pérez, J.; Egesi, C.; Cuambe, C.; Escobar, A.; Ortiz, D.; Chávez, A.L. Tolerance to postharvest physiological deterioration in cassava roots. Crop Sci. 2010, 50, 1333-1338. [CrossRef]

35. Djabou, A.S.; Carvalho, L.J.; Li, Q.X.; Niemenak, N.; Chen, S. Cassava postharvest physiological deterioration: A complex phenomenon involving calcium signaling, reactive oxygen species and programmed cell death. Acta Physiol. Plant. 2017, 39, 91. [CrossRef]

36. Abass, A.; Onabolu, A.; Bokanga, M. Impact of the high quality cassava flour technology in Nigeria. In Proceedings of the 7th Triennial Symposium of the International Society for Tropical Root Crops Africa Branch (ISTRC-AB), Cotonou, Benin, 11-17 October 1998.

37. Amoa-Awua, W.K.; Owusu, M.; Feglo, P. Utilization of unfermented cassava flour for the production of an indigenous African fermented food, agbelima. World J. Microbiol. Biotechnol. 2005, 21, 1201-1207. [CrossRef]

38. Quaye, W.; Gayin, J.; Yawson, I.; Plahar, W.A. Characteristics of Various Cassava Processing Methods and the Adoption Requirements in Ghana. 2009. Available online: http:/ / hdl.handle.net/123456789/1026 (accessed on 30 March 2020).

39. Navia, D.P.; Villada, H.S. Thermoplastic Cassava Flour; El-Sonbati, A.Z., Ed.; InTech: Rijeka, Croatia, 2012; pp. 23-38. [CrossRef]

40. Aristizábal, J.; García, J.A.; Ospina, B. Refined cassava flour in bread making: A review. Ing. E Investig. 2017, 37, 25-33. [CrossRef]

41. Dziedzoave, N.; Graffham, A.; Boateng, E. Training Manual for the Production of High Quality Cassava Flour. 2004. Available online: https: / /agris.fao.org/agris-search/search.do?recordID=GB2012100904 (accessed on 5 August 2021).

42. Eriksson, E. Flour from Three Local Varieties of Cassava (Manihot esculenta Crantz)-Physico-Chemical Properties, Bread Making Quality and Sensory Evaluation. Master's Thesis, Swedish University of Agricultural Science, Uppsala, Uppsala, 2013 ; p. 17.

43. Falade, K.O.; Ibanga-Bamijoko, B.; Ayetigbo, O.E. Comparing properties of starch and flour of yellow-flesh cassava cultivars and effects of modifications on properties of their starch. J. Food Meas. Charact. 2019, 13, 2581-2593. [CrossRef]

44. Udoro, E.O.; Anyasi, T.A.; Jideani, A.I.O. Characterization of the root and flour of South African Manihot esculenta Crantz landraces and their potential end-use properties. Int. J. Food Prop. 2020, 23, 820-838. [CrossRef]

45. Apea-Bah, F.; Oduro, I.; Ellis, W.; Safo-Kantanka, O. Factor analysis and age at harvest effect on the quality of flour from four cassava varieties. World J. Dairy Food Sci. 2011, 6, 43-54.

46. Adesina, B.; Bolaji, O. Effect of milling machines and sieve sizes on cooked cassava flour quality. Niger. Food J. 2013, 31, 115-119. [CrossRef]

47. Olukunle, O.; Oguntunde, P. Analysis of peeling pattern in an automated cassava peeling system. Niger. J. Technol. Dev. 2008, 6, 2.

48. Olukunle, O.J.; Ogunlowo, A.; Sanni, L. The Search for an Effective Cassava Peeler. West Indian J. Eng. 2010, 32, $42-47$.

49. Jimoh, M.; Olukunle, O.; Manuwa, S.; Amumeji, O. Theoretical analysis of tuber movement during mechanical peeling of cassava. J. Mech. Civ. Eng. 2014, 6, 27-36. [CrossRef]

50. Egbeocha, C.; Asoegwu, S.; Okereke, N. A review on performance of cassava peeling machines in Nigeria. Futo J. Ser. (FUTOJNLS) 2016, 2, 140-168.

51. Fernandez, A.; Wenham, J.; Dufour, D.; Wheatley, C. The Influence of Variety and Processing on the Physicochemical and Functional Properties of Cassava Starch and Flour. 1996, pp. 263-269. Available online: https:/ /books.google.com.hk/books?hl=zh-

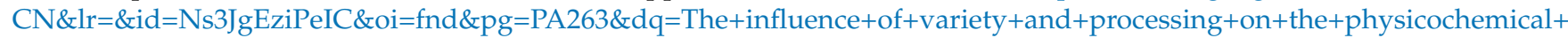
and+functional+properties+of+cassava+starch+and+flour.\&ots=ZNWcdDCQXb\&sig=QoKOAkbFYASsihs5QnG8jcE4WVQ\& redir_esc $=\mathrm{y} \# \mathrm{v}=$ onepage\&q\&f$=$ false (accessed on 5 August 2021).

52. Irinkoyenikan, O.; Taiwo, K.; Gbadamosi, S.; Akanbi, C. Studies of fufu production from cassava chips. In Proceedings of the Humboldt-Kolleg Held at the Obafemi Awolowo University, Ile-Ife, Nigeria, 5-9 December 2008; pp. 117-132.

53. Aryee, F.; Oduro, I.; Ellis, W.; Afuakwa, J. The physicochemical properties of flour samples from the roots of 31 varieties of cassava. Food Control 2006, 17, 916-922. [CrossRef]

54. Kusumayanti, H.; Handayani, N.A.; Santosa, H. Swelling Power and Water Solubility of Cassava and Sweet Potatoes Flour. Procedia Environ. Sci. 2015, 23, 164-167. [CrossRef]

55. Pereira, B.L.B.; Leonel, M. Resistant starch in cassava products. Food Sci. Technol. 2014, 34, 298-302. [CrossRef]

56. Akindahunsi, A.; Oboh, G.; Oshodi, A. Effect of fermenting cassava with Rhizopus oryzae on the chemical composition of its flour and gari products. Riv. Ital. Delle Sostanze Grasse 1999, 76, 437-440.

57. Padonou, S.W.; Hounhouigan, J.D.; Nago, M.C. Physical, chemical and microbiological characteristics of lafun produced in Benin. Afr. J. Biotechnol. 2009, 8, 14.

58. Padonou, S.W.; Nielsen, D.S.; Hounhouigan, J.D.; Thorsen, L.; Nago, M.C.; Jakobsen, M. The microbiota of Lafun, an African traditional cassava food product. Int. J. Food Microbiol. 2009, 133, 22-30. [CrossRef]

59. Oboh, G.; Akindahunsi, A. Biochemical changes in cassava products (flour \& gari) subjected to Saccharomyces cerevisae solid media fermentation. Food Chem. 2003, 82, 599-602. 
60. Oboh, G.; Akindahunsi, A. Nutritional and toxicological evaluation of Saccharomyces cerevisae fermented cassava flour. J. Food Compos. Anal. 2005, 18, 731-738. [CrossRef]

61. Oboh, G.; Oladunmoye, M. Biochemical changes in micro-fungi fermented cassava flour produced from low-and medium-cyanide variety of cassava tubers. Nutr. Health 2007, 18, 355-367. [CrossRef]

62. Sulistyo, J.; Shya, L.J.; Mamat, H.; Wahab, N.A. Nutritional value of fortified cassava flour prepared from modified cassava flour and fermented protein hydrolysates. In Proceedings of the 4th International Conference of Biological Sciences, Yogyakarta, Indonesia, 18-19 September 2015; p. 020030.

63. Wahyuni, S. Physico-chemical properties of Wikau maombo flour from cassava (Manihot esculenta Crantz). J. Food Meas. Charact. 2017, 11, 329-336. [CrossRef]

64. Chukwuemeka, O.C. Effect of process modification on the physio-chemical and sensory quality of fufu-flour and dough. Afr. J. Biotechnol. 2007, 6, 1949-1953.

65. Rodríguez-Sandoval, E.; Fernández-Quintero, A.; Cuvelier, G.; Relkin, P.; Bello-Pérez, L.A. Starch retrogradation in cassava flour from cooked parenchyma. Starch-Stärke 2008, 60, 174-180. [CrossRef]

66. Murayama, D.; Kasano, M.; Santiago, D.M.; Yamauchi, H.; Koaze, H. Effect of pre-gelatinization on the physicochemical properties of dry flours produced from 5 cassava varieties of the Philippines. Food Sci. Technol. Res. 2014, 20, 1131-1140. [CrossRef]

67. Uchechukwu-Agua, A.D.; Caleb, O.J.; Manley, M.; Opara, U.L. Effects of storage conditions and duration on physicochemical and microbial quality of the flour of two cassava cultivars (TME 419 and UMUCASS 36). CyTA-J. Food 2015, 13, 635-645. [CrossRef]

68. Opara, U.L.; Caleb, O.J.; Uchechukwu-Agua, A.D. Evaluating the impacts of selected packaging materials on the quality attributes of cassava flour (cvs. TME 419 and UMUCASS 36). J. Food Sci. 2016, 81, C324-C331. [CrossRef] [PubMed]

69. Charoenkul, N.; Uttapap, D.; Pathipanawat, W.; Takeda, Y. Physicochemical characteristics of starches and flours from cassava varieties having different cooked root textures. LWT-Food Sci. Technol. 2011, 44, 1774-1781. [CrossRef]

70. Moorthy, S.; Wenham, J.E.; Blanshard, J.M. Effect of solvent extraction on the gelatinisation properties of flour and starch of five cassava varieties. J. Sci. Food Agric. 1996, 72, 329-336. [CrossRef]

71. Niba, L.; Bokanga, M.; Jackson, F.; Schlimme, D.; Li, B. Physicochemical properties and starch granular characteristics of flour from various Manihot esculenta (cassava) genotypes. J. Food Sci. 2002, 67, 1701-1705. [CrossRef]

72. Tonukari, N.J. Cassava and the future of starch. Electron. J. Biotechnol. 2004, 7, 5-8. [CrossRef]

73. Taiwo, K.A. Utilization potentials of cassava in Nigeria: The domestic and industrial products. Food Rev. Int. 2006, 22, 29-42. [CrossRef]

74. Uchechukwu-Agua, A.D.; Caleb, O.J.; Opara, U.L. Postharvest handling and storage of fresh cassava root and products: A review. Food Bioprocess Technol. 2015, 8, 729-748. [CrossRef]

75. Jekayinfa, S.; Olajide, J. Analysis of energy usage in the production of three selected cassava-based foods in Nigeria. J. Food Eng. 2007, 82, 217-226. [CrossRef]

76. Olaoye, O.A.; Ade-Omowaye, B.I. Composite flours and breads: Potential of local crops in developing countries. In Flour and Breads and Their Fortification in Health and Disease Prevention; Elsevier: Amsterdam, The Netherlands, 2011; pp. 183-192.

77. Iwuoha, C.; Ezumba, C.; Nnadozie, C. Effect of steaming on the proximate composition and physico-chemical properties of fufu flour made from two cassava varieties (Manihot esculenta Crantz and Manihot palmata, Muell). Niger. Food J. 2003, $21,54-61$.

78. Tomlins, K.; Sanni, L.; Oyewole, O.; Dipeolu, A.; Ayinde, I.; Adebayo, K.; Westby, A. Consumer acceptability and sensory evaluation of a fermented cassava product (Nigerian fufu). J. Sci. Food Agric. 2007, 87, 1949-1956. [CrossRef]

79. Jumah, A.; Dipeolu, A.O.; Ayinde, I.A.; Adebayo, K. An LA-AIDS analysis of cassava food products demand in Lagos. J. Dev. Areas 2008, 41, 109-117. [CrossRef]

80. Jumah, A.; Johnson, P.N.T.; Quayson, E.T.; Tortoe, C.; Oduro-Yeboah, C. Market testing of a major cassava flour product in the Accra metropolitan area. Int. J. Consum. Stud. 2008, 32, 687-691. [CrossRef]

81. Adebayo-Oyetoro, A.; Oyewole, O.; Obadina, A.; Omemu, M. Microbiological safety assessment of fermented cassava flour "lafun" available in Ogun and Oyo states of Nigeria. Int. J. Food Sci. 2013, 2013, 1-5. [CrossRef] [PubMed]

82. Bamidele, O.P.; Fasogbon, M.B.; Oladiran, D.A.; Akande, E.O. Nutritional composition of fufu analog flour produced from Cassava root (Manihot esculenta) and Cocoyam (Colocasia esculenta) tuber. Food Sci. Nutr. 2015, 3, 597-603. [CrossRef]

83. Lim, T. Manihot esculenta. In Edible Medicinal and Non-Medicinal Plants; Springer: Berlin/Heidelberg, Germany, 2016; pp. 308-353.

84. Taiwo, K.; Gbadamosi, S.; Izevbekhai, E.; Famuwagun, A.; Ajani, R.; Akanbi, C. Influence of Drying Methods and Soaking Media on Lafun Processed from Cassava Chips. Curr. J. Appl. Sci. Technol. 2016, 16, 1-14. [CrossRef]

85. Sira, E.E.P.; Amaiz, M.L.; González, Z.; Tovar, J. Production and characterization of cassava (Manihot esculenta Crantz) flours using different thermal treatments. Interciencia 2007, 32, 615-619.

86. Silva, D.; Santos, J.; Ferreira, E.; Silva, A.; França, A.; Sediyama, T. Manejo de plantas daninhas na cultura da mandioca. Planta Daninha 2012, 30, 901-910. [CrossRef]

87. Chisté, R.C.; Cardoso, J.M.; Silva, D.A.d.; Pena, R.d.S. Hygroscopic behaviour of cassava flour from dry and water groups. Ciência Rural 2015, 45, 1515-1521. [CrossRef]

88. Sajeev, M.S.; Sreekumar, J.; Unnikrishnan, M.; Moorthy, S.; Shanavas, S. Kinetics of thermal softening of cassava tubers and rheological modeling of the starch. J. Food Sci. Technol. 2010, 47, 507-518. [CrossRef]

89. Manano, J.; Ogwok, P.; Byarugaba-Bazirake, G.W. Chemical composition of major cassava varieties in Uganda, targeted for industrialisation. J. Food Res. 2017, 7, 1-9. [CrossRef] 
90. Maziya-Dixon, B.; Dixon, A.G.; Adebowale, A.R.A. Targeting different end uses of cassava: Genotypic variations for cyanogenic potentials and pasting properties. Int. J. Food Sci. Technol. 2007, 42, 969-976. [CrossRef]

91. Eleazu, C.; Eleazu, K. Determination of the proximate composition, total carotenoid, reducing sugars and residual cyanide levels of flours of 6 new yellow and white cassava (Manihot esculenta Crantz) varieties. Am. J. Food Technol. 2012, 7, 642-649. [CrossRef]

92. Oliveira, R.A.; De Carvalho, M.L.; Nutti, R.M.; De Carvalho, L.J.; Fukuda, W.G. Assessment and degradation study of total carotenoid and B-carotene in bitter yellow cassava (Manihot esculenta Crantz) varieties. Embrapa Agroindústria Aliment.-Artig. Em Periódico Indexado (ALICE) 2010, 4, 148-155.

93. Rodríguez-Sandoval, E.; Fernández-Quintero, A.; Sandoval-Aldana, A.; Cuvelier, G. Effect of processing conditions on the texture of reconstituted cassava dough. Braz. J. Chem. Eng. 2008, 25, 713-722. [CrossRef]

94. Steinkraus, K. Handbook of Indigenous Fermented Foods, Revised and Expanded; CRC Press: Boca Raton, FL, USA, 2018. [CrossRef]

95. Aro, S. Improvement in the nutritive quality of cassava and its by-products through microbial fermentation. Afr. J. Biotechnol. 2008, 7, 4789-4797.

96. Oboh, G.; Akindahunsi, A.; Oshodi, A. Aflatoxin and moisture content of micro-fungi. Appl. Trop. Agric. $2000,5,154-157$.

97. Omolola, A.O.; Kapila, P.F.; Anyasi, T.A.; Jideani, A.I.O.; McHau, G.A. Optimization of Color and Thermal Properties of Sweet Cassava (Manihot esculenta Crantz Var. UVLNR 0005) Flour Using Response Surface Methodology. Asian J. Agric. Res. 2017, 11, 57-65. [CrossRef]

98. Eduardo, M.; Svanberg, U.; Oliveira, J.; Ahrné, L. Effect of cassava flour characteristics on properties of cassava-wheat-maize composite bread types. Int. J. Food Sci. 2013, 2013, 1-10. [CrossRef] [PubMed]

99. Oladunmoye, O.; Akinoso, R.; Olapade, A. Evaluation of some physical-chemical properties of wheat, cassava, maize and cowpea flours for bread making. J. Food Qual. 2010, 33, 693-708. [CrossRef]

100. Chisenga, S.M.; Workneh, T.S.; Bultosa, G.; Laing, M. Proximate composition, cyanide contents, and particle size distribution of cassava flour from cassava varieties in Zambia. AIMS Agric. Food 2019, 4, 869. [CrossRef]

101. Sahin, S.; Sumnu, S.G. Physical Properties of Foods; Springer Science \& Business Media: Berlin/Heidelberg, Germany, 2006; Available online: https://books.google.co.za/books?id=v854Fu2D7VUC\&lpg=PA1\&ots=FzqVCs81lo\&dq=Sahin\%2C\%20S.\%3 B\%20Sumnu\%2C\%20S.G.\%20Physical\%20Properties\%20of\%20Foods\%3B \%20Springer \%20Science $\% 20 \% 26 \% 20 \mathrm{Business} \% 20$ Media\%3A\%20\&lr\&pg=PA1\#v=onepage\&q\&f=false (accessed on 13 September 2020).

102. Lépiz-Aguilar, L.; Rodríguez-Rodríguez, C.E.; Arias, M.L.; Lutz, G. Acetone-Butanol-Ethanol (ABE) production in fermentation of enzymatically hydrolyzed cassava flour by Clostridium beijerinckii BA101 and solvent separation. J. Microbiol. Biotechnol. 2013, 23, 1092-1098. [CrossRef]

103. Jisha, S.; Padmaja, G.; Moorthy, S.; Rajeshkumar, K. Pre-treatment effect on the nutritional and functional properties of selected cassava-based composite flours. Innov. Food Sci. Emerg. Technol. 2008, 9, 587-592. [CrossRef]

104. Jisha, S.; Padmaja, G.; Sajeev, M. Nutritional and textural studies on dietary fiber-enriched muffins and biscuits from cassava-based composite flours. J. Food Qual. 2010, 33, 79-99. [CrossRef]

105. Ogiehor, I.; Ikenebomeh, M. The effects of different packaging materials on the shelf stability of garri. Afr. J. Biotechnol. 2006, 23, 2412-2416.

106. Opara, U.L.; Al-Ani, M.R. Effects of cooking methods on carotenoids content of Omani kingfish (Scomeberomorus commerson L.). Br. Food J. 2010, 112, 811-820. [CrossRef]

107. Cazumbá da Silva, Í.R.; Cardoso, R.d.C.V.; Góes, J.Â.W.; Druzian, J.I.; Vidal Júnior, P.O.; de Andrade, A.C.B. Food safety in cassava "flour houses" of Copioba Valley, Bahia, Brazil: Diagnosis and contribution to geographical indication. Food Control 2017, 72, 97-104. [CrossRef]

108. Oyewole, O.B.; Sanni, L. Constraints in Traditional Cassava Processing: The Case of" FUFU" Production= Les Contraintes au Cours de la Transformation Traditionnelle du Manioc: Le cas de la Production de Foufou; Agbor-Egbe, T., Brauman, A., Griffon, D., Treche, S., Eds.; CIAT: Cali, Columbia, 1995; pp. 523-529.

109. Gacheru, P.; Abong, G.; Okoth, M.; Lamuka, P.; Shibairo, S.; Katama, C. Microbiological safety and quality of dried cassava chips and flour sold in the Nairobi and coastal regions of Kenya. Afr. Crop Sci. J. 2016, 24, 137-143. [CrossRef]

110. Steenkamp, V.; McCrindle, C. Production, consumption and nutritional value of cassava (Manihot esculenta, Crantz) in Mozambique: An overview. J. Agric. Biotechnol. Sustain. Dev. 2014, 6, 29-38.

111. Dada, O.A.; Oworu, O.O. Mineral and nutrient leaf composition of two cassava (Manihot esculenta Crantz) cultivars defoliated at varying phenological phases. Not. Sci. Biol. 2010, 2, 44-48. [CrossRef]

112. El-Sharkawy, M.A. Physiological characteristics of cassava tolerance to prolonged drought in the tropics: Implications for breeding cultivars adapted to seasonally dry and semiarid environments. Braz. J. Plant Physiol. 2007, 19, 257-286. [CrossRef]

113. Briani, C.; Samaroo, D.; Alaedini, A. Celiac disease: From gluten to autoimmunity. Autoimmun. Rev. 2008, 7, 644-650. [CrossRef] [PubMed]

114. Torbica, A.; Hadnađev, M.; Dapčević, T. Rheological, textural and sensory properties of gluten-free bread formulations based on rice and buckwheat flour. Food Hydrocoll. 2010, 24, 626-632. [CrossRef]

115. Nugent, A.P. Health properties of resistant starch. Nutr. Bull. 2005, 30, 27-54. [CrossRef]

116. Alobo, A.; Arueya, G. Physical, functional and chemical properties of Grewia venusta (Ururu) mucilage extract. Int. Food Res. J. 2017, 24, 2107-2115. 
117. Olatunde, S.J.; Oyeyinka, S.A.; Adetola, R.O.; Oyeyinka, A.T.; Owolabi, T. Physicochemical properties of pro-vitamin A cassavawheat composite flour biscuit. Hrana U Zdr. I Boles. Znan.-Stručni Časopis Za Nutr. I Dijetetiku 2016, 5, $20-26$.

118. Abidin, A.Z.; Devi, C.; Adeline, A. Development of wet noodles based on cassava flour. J. Eng. Technol. Sci. 2013, 45, 97-111. [CrossRef]

119. Falade, K.O.; Akingbala, J.O. Improved Nutrition and National Development through the Utilization of Cassava in Baked Foods. Available online: http://www.iufost.org/publications/books/documents/Chapter10FaladeAkingbala.pdf (accessed on 30 March 2020).

120. Purwadi, R.; Teguh, C.; Mazaya, D. Fermented cassava as an alternative flour for pasta noodle. In Proceedings of the IOP Conference Series: Materials Science and Engineering, Lisbon, Portugal, 23-25 June 2021; p. 012042.

121. Abass, A.; Awoyale, W.; Alenkhe, B.; Malu, N.; Asiru, B.; Manyong, V.; Sanginga, N. Can food technology innovation change the status of a food security crop? A review of cassava transformation into "bread" in Africa. Food Rev. Int. 2018, 34, 87-102. [CrossRef]

122. Ferraro, V.; Piccirillo, C.; Tomlins, K.; Pintado, M.E. Cassava (Manihot esculenta Crantz) and yam (Dioscorea spp.) crops and their derived foodstuffs: Safety, security and nutritional value. Crit. Rev. Food Sci. Nutr. 2016, 56, 2714-2727. [CrossRef] [PubMed]

123. Parmar, A.; Sturm, B.; Hensel, O. Crops that feed the world: Production and improvement of cassava for food, feed, and industrial uses. Food Secur. 2017, 9, 907-927. [CrossRef]

124. Obadina, A.; Oyewole, O.; Olaniyi, G. Effect of baking improvers on the quality of whole cassava biscuits. J. Food Sci. Technol. 2014, 51, 2803-2808. [CrossRef]

125. Akubor, P.; Ukwuru, M. Functional properties and biscuit making potential of soybean and cassava flour blends. Plant Foods Hum. Nutr. 2003, 58, 1-12. [CrossRef]

126. Thomas, O.O. The Effect of Soybean Pre-Treatment on The Sensory Properties of Cassava-Soy Flour Biscuit. Master's Thesis, Department of Food Science and Technology, College of Food Science and Human Ecology, Federal University of Agriculture, Abeokuta, Nigeria, 2012.

127. Nwabueze, T.U.; Anoruoh, G.A. Evaluation of flour and extruded noodles from eight cassava mosaic disease (CMD)-resistant varieties. Food Bioprocess Technol. 2011, 4, 80-91. [CrossRef]

128. Maziya-Dixon, B.; Alamu, E.O.; Popoola, I.O.; Yomeni, M. Nutritional and sensory properties: Snack food made from high-quality cassava flour and legume blend. Food Sci. Nutr. 2017, 5, 805-811. [CrossRef] [PubMed]

129. Owuamanam, C.; Ogueke, C.; Ihediohanma, N.; Omeire, G.; Omeni, C. Blending of acetylated cassava starch, cassava flour and wheat flour for composite in bread making. Br. J. Appl. Sci. Technol. 2015, 10, 1-9. [CrossRef]

130. Nwosu, J.N.; Owuamanam, C.; Omeire, G.; Eke, C. Quality parameters of bread produced from substitution of wheat flour with cassava flour using soybean as an improver. Am. J. Res. Commun. 2014, 2, 99-118.

131. Eddy, N.; Udofia, P.; Eyo, D. Sensory evaluation of wheat/cassava composite bread and effect of label information on acceptance and preference. Afr. J. Biotechnol. 2007, 6. [CrossRef]

132. Shittu, T.; Dixon, A.; Awonorin, S.; Sanni, L.O.; Maziya-Dixon, B. Bread from composite cassava-wheat flour. II: Effect of cassava genotype and nitrogen fertilizer on bread quality. Food Res. Int. 2008, 41, 569-578. [CrossRef]

133. Shittu, T.; Raji, A.; Sanni, L. Bread from composite cassava-wheat flour: I. Effect of baking time and temperature on some physical properties of bread loaf. Food Res. Int. 2007, 40, 280-290. [CrossRef]

134. Shittu, T.A.; Aminu, R.A.; Abulude, E.O. Functional effects of xanthan gum on composite cassava-wheat dough and bread. Food Hydrocoll. 2009, 23, 2254-2260. [CrossRef]

135. Aboaba, O.; Obakpolor, E. The leavening ability of bakers' yeast on dough prepared with composite flour (Wheat/Cassava). Afr. J. Food Sci. 2010, 4, 325-329.

136. Oladunmoye, O.O.; Ojo, A.; Akinoso, R.; Akanbi, C.T. Thermo-physical properties of composite bread dough with maize and cassava flours. Int. J. Food Sci. Technol. 2010, 45, 587-593. [CrossRef]

137. Adeboye, A.; Babajide, J.; Shittu, T.; Omemu, A.; Oluwatola, O. Effect of honey as partial sugar substitute on pasting properties, consumer preference and shelf stability of cassava-wheat composite bread. Niger. Food J. 2013, 31, 13-22. [CrossRef]

138. Eriksson, E.; Koch, K.; Akonor, P.; Oduro-Yeboah, C. Evaluation of the Physical and Sensory Characteristics of Bread Produced from Three Varieties of Cassava and Wheat Composite Flours. 2014. Available online: http://hdl.handle.net/123456789/543 (accessed on 22 July 2021).

139. Jensen, S.; Skibsted, L.H.; Kidmose, U.; Thybo, A.K. Addition of cassava flours in bread-making: Sensory and textural evaluation. LWT-Food Sci. Technol. 2015, 60, 292-299. [CrossRef]

140. Alobo, A.P.; Arueya, G.L. Effect of Grewia venusta fresen mucilage on the proximate composition, physical and Sensory properties of bread produced from wheat and cassava composite flours. Int. J. Food Stud. 2017, 6, 192-200. [CrossRef]

141. Iwe, M.; Michael, N.; Madu, N.; Obasi, N.; Onwuka, G.; Nwabueze, T. Production and evaluation of bread made from high quality cassava flour (HQCF) and Wheat Flour Blends. Agrotechnology 2017, 6, 166.

142. Akonor, P.; Tortoe, C.; Buckman, E.; Hagan, L. Proximate composition and sensory evaluation of root and tuber composite flour noodles. Cogent Food Agric. 2017, 3, 1292586. [CrossRef]

143. Bolade, M.K.; Adeyemi, I.A. Functionality enhancement of composite cassava flour in the production of maize tuwo (a nonfermented maize-based food dumpling). Food Bioprocess Technol. 2012, 5, 1340-1348. [CrossRef] 
144. Akinwande, B.; Ade-Omowaye, B.; Olaniyan, S.; Akintaro, O. Quality evaluation of ginger flavoured soy-cassava biscuit. Nutr. Food Sci. 2008, 38, 473-481. [CrossRef]

145. Aly, M.M.; Seleem, H.A. Gluten-free flat bread and biscuits production by cassava, extruded soy protein and pumpkin powder. Food Nutr. Sci. 2015, 6, 660. [CrossRef]

146. Oluwamukomi, M.; Oluwalana, I.; Akinbowale, O. Physicochemical and sensory properties of wheat-cassava composite biscuit enriched with soy flour. Afr. J. Food Sci. 2011, 5, 50-56.

147. Oluwole, O.; Karim, O. Production of biscuits from Bambara, cassava and wheat flour blends. J. Raw Mater. Res. 2005,2 , 34-38.

148. Gyedu-Akoto, E.; Laryea, D. Evaluation of cassava flour in the production of cocoa powder-based biscuits. Nutr. Food Sci. 2013, 43, 55-59. [CrossRef]

149. Ammar, A.; El-Razik, A. Quality characteristics of gluten free cake produced from cassava, pumpkin and potato flours. J. Food Dairy Sci. 2013, 4, 401-412. [CrossRef]

150. Olapade, A.A.; Adeyemo, M.A. Evaluation of cookies produced from blends of wheat, cassava and cowpea flours. Int. J. Food Stud. 2014, 3. [CrossRef] 